\title{
Niazboo (Ocimum Basilicum) As Medicinal Plant Establishes Against Salinity and Sodicity
}

\author{
Muhammad Arshad Ullah ${ }^{1 *}$, Muhammad Rasheed ${ }^{2}$ and Imdad Ali Mahmood ${ }^{1}$ \\ ${ }^{1}$ Land Resources Research Institute, National Agricultural Research Centre, Pakistan \\ ${ }^{2}$ Department of PMAS - Agronomy, University of Arid Agriculture, Pakistan
}

Submission: November 20,2018; Published: February 13, 2019

*Corresponding author: Muhammad Arshad Ullah, Land Resources Research Institute, National Agricultural Research Centre, Islamabad, Pakistan

\begin{abstract}
Salt stress is one of the most serious limiting factors for crop growth and production. Salinity stress negatively impacts the growth and yield of plants. Niazboo (Ocimum basilicum). This experiment was conducted to evaluate the effects of $\left(4 \mathrm{dSm}^{-1}+13.5\left(\mathrm{mmol} \mathrm{L}^{-1}\right) 1 / 2,5 \mathrm{dSm}^{-1}+\right.$ $25\left(\mathrm{mmol} \mathrm{L}^{-1}\right)^{1 / 2}, 5 \mathrm{dSm}^{-1}+30\left(\mathrm{mmol} \mathrm{L}^{-1}\right)^{1 / 2}, 10 \mathrm{dSm}^{-1}+25\left(\mathrm{mmol} \mathrm{L}^{-1}\right)^{1 / 2}$ and $10 \mathrm{dSm}^{-1}+30\left(\mathrm{mmol} \mathrm{L}^{-1}\right)^{1 / 2}$ on biomass yield of guar against salinity tolerance. Maximum biomass yield $\left(43.10 \mathrm{gpot}^{-1}\right)$ was produced by $4 \mathrm{dSm}^{-1}+13.5\left(\mathrm{mmol} \mathrm{L}^{-1}\right)^{1 / 2}$ treatment. Biomass produce was reduced with the increase of the salt's toxicity. Minimum biomass yield $\left(30.33 \mathrm{gpot}^{-1}\right)$ was attained under $10 \mathrm{dSm}^{-1}+30\left(\mathrm{mmol} \mathrm{L}^{-1}\right)^{1 / 2} .5 \mathrm{dSm}^{-1}+25\left(\mathrm{mmol} \mathrm{L}^{-1}\right)^{1 / 2}$ treatment exhibited improved outcome i.e. the least diminution \% over control (11.83). Salinity cum sodicity showed staid effect on the growth reduction from $11.83 \%$ to $29.62 \%$. This reduction fissure was impacted by the toxic effect of salinity and sodicity on Guar growth. Salinitysodicity behaved toxic impact on the growth reduction from $11.83 \%$ to $29.62 \%$. Based on the findings, Niazboo (Ocimum basilicum) establishes better at $4 \mathrm{dSm}^{-1}+13.5\left(\mathrm{mmol} \mathrm{L}^{-1}\right)^{1 / 2}$ treatment.
\end{abstract}

Keywords: Niazboo (Ocimum basilicum); Saline- sodic; Medicinal value; Biomass yield

\section{Introduction}

Salinity stress negatively impacts agricultural yields throughout the world, affecting production, whether for subsistence or economic gain. At present, about $20 \%$ of the world's cultivated land and approximately half of all irrigated land and $2.1 \%$ of the dry agriculture land is affected by salinity. Salinization is spreading more rapidly in irrigated lands because of inappropriate management of irrigation and drainage. Moreover, rain, cyclones and wind add $\mathrm{NaCl}$ to coastal agricultural lands. The rapid increase in the world's population requires an expansion of crop areas to raise food production. Salinity imposes serious environmental problems that affect grassland cover and the availability of animal feed in arid and semiarid regions. Salt stress is one of the most serious limiting factors for crop growth and production in the arid regions. About $23 \%$ of the world's cultivated lands is saline and $37 \%$ is sodic [1]. Considerable research work has been conducted on the effect of salinity on different growth characters of different crops worldwide [2-9].

Niazboo (Ocimum basilicum) commonly known as sweet basil is a popular herbaceous plant belongs to Lamiaceae family widely used for flavoring and medicinal purposes. It is an annual herb, 20$60 \mathrm{~cm}$ plant height with white and pink flowers and characterized by great morphological and chemical diversity. The useful parts of the plants are leaves and seeds, these highly aromatic leaves used either fresh or dried for spice. It comprises 65 species, adapted to grow in warm conditions and originally it is native to India and other countries of Asia [10].

Hot tea of basil plant leaves is good for treating nausea, dysentery and flatulence. Externally it can be used for different skin infections such as treatment of acne, snake bites and insect stings. In addition to these, basil has been used as a remedy for an enormous number of ailments, including cancer, convulsion, deafness, diarrhea, epilepsy, insanity, sore throat, toothaches, and whooping cough. Ocimum basilicum is being utilized as a source of essential oils mainly in industries, perfumery, dental, oral products and traditional ritual. As a part of the tradition and religious rituals, basil needs more attention for the furtherance of its cultivation on a commercial scale as compared to other medicinally important plants. The aim of this study is to promote the cultivation of basil plants as well as utilization of saline lands which are unproductive for a number of field crops and reduce the average output of major crops greater than 50\% [11].

Ocimum basilicum L., commonly known as Sweet Basil, belongs to the genus Ocimum of the family Lamiaceae. Ocimum (from Greek ozo for smell) is appropriate for the genus since its various species are known for their peculiar strong odours. Basilicum is the Latin translation of the Greek basilikon meaning king and 
due perhaps the same reason the herb is called "Herbe Royale" in French. The Urdu/Punjabi name Niazbo is also reflective of its pleasant fragrance.

Various effects like immunomodulatory, hyperglcaemic, hypolipidemic, anti-inflammatory, hepatoprotective, antimutagenic, antimicrobial, antifungal, antioxidant, lipid peroxidation, insect repellency, antiviral, antierythmic, depigmenting, antitoxic and CNS activity analysis reports are mentioned. The wide range of study on this herbal plant shows that it is very beneficial for the improvement of current drugs and more work can be done to take advantage of the potential remedial qualities of it. It is reported that some plant seeds showed major reduce under salt stress i.e. Ocimum basilicum [12], Petroselinum hortense [13], sweet marjoram [14] and Thymus maroccanus [15]. The other stage is seedling growth which influenced by salinity negatively. It has been reported that, seedling growth of Thymus maroccanus [15], basil, chamomile and marjoram [14] were severely decreased depend on salt stress. Some researchers said that morphological characteristics of number of medicinal plants were effected under salt stress conditions such as number of leaves, leaf area and leaf biomas in reduced form as Majorana hortensis, peppermint, geranium, Thymus vulgaris, sage and Mentha pulegium [16-21].

In this study, sweet basil was used as an experimental material. This plant is commonly used by local people in treatments of various diseases. For example, it is used for treatment of dry mouth and dental complaints, diarrhea and chronic dysentery, respiratory disorders, and effective in the treatment of fungal diseases and stomach discomfort in addition, the influential antitussive, diuretic, anthelminthic, tranquilizer and expectorant roles in medicinal approach [22,23].

The use of medicinal plants on phytotherapy is a result of empirical knowledge accumulated over the centuries about plant actions in several ethnic groups. Therefore, there are many questions about the standardization techniques for the production and exchange of phototherapeutic agents [24].

The indiscriminate medicinal use of plants, usually toxic ones, may entail risks to health, because, similarly to the allopathic drugs, there is a threshold dosage for each phytotherapeutic agent. Thus, after an inadequate use, several disorders may occur, from intoxications to mutation events in somatic and germinative tissue, and it can lead to the development of somatic diseases, teratogenic effects and inherited genetic damages [25-28]. Most carcinogens, for example, trigger their tumorigenic activity by the interaction of natural inductors of mutations with the DNA, leading to permanent genetic lesions, which are expressed as genetic mutations or chromosomal aberrations involving the cell cycle [29].

The presence of secondary metabolites in plants is characterized by their ability to provide defenses against biotic and abiotic stress [30]. The mechanism of defense varies from plant to plant, their environmental conditions and climatic variations. However, the presence of these metabolites in plant are usually in minimum amounts though several molecular techniques are available to either increase or decrease the quantity of a particular metabolite by blocking competitive pathways and enriching metabolites of choice [31]. Terpenes, alkaloids (N-containing compounds) and phenolics constitute the largest groups of secondary metabolites. The shikimic acid pathway is the basis of the biosynthesis of phenolics while the terpenes which are comprised of isoprene units arise from the mevalonate pathway [32].

Aspirin (1) from white willow, quinine (2) from the cinchona plant and artemisinin (3) from Artemisia annum are all plant secondary metabolites. The biological application of these metabolites as therapeutic agents for a broad spectrum of ailments and the microbial infections has been salutary in human history.

Aromatic and medicinal plants are still a major part of alternative and traditional medicine in the developing countries. Numerous herbal therapies are currently widely used in medicine $[33,34]$. The use of medicinal herbs as anti-inflammatory, antifungal, and analgesic drugs is common in Algeria. In most cases, the active molecules of the herbs are unknown. Studying the biological and pharmacological properties of medicinal plant extracts is a rational approach in our quest for new drugs [35-38].

\section{Materials and Methods}

A pot study was conducted to evaluate the salt tolerance of Niazboo (Ocimum basilicum) as medicinal plant under different saline and sodic concentrations at green house of Land Resources Research Institute, National Agricultural Research Centre, Islamabad, Pakistan during, 2017. The soil used for the pot experiment was analysed and having $7.4 \mathrm{pH}, 1.7 \mathrm{ECe}\left(\mathrm{dSm}^{-1}\right)$, 4.9 SAR $\left(\mathrm{mmol} \mathrm{L}^{-1}\right)^{1 / 2}, 21.7$ Saturation Percentage (\%), 0.40 0.M. (\%), 7.0 Available P (mg Kg-1) and 97.7 Extractable $\mathrm{K}\left(\mathrm{mg} \mathrm{Kg}^{-1}\right)$. Considering the pre- sowing soil analysis, the ECe (Electrical Conductivity) and SAR (Sodium Absorption Ratio) was artificially developed with salts of $\mathrm{NaCl}, \mathrm{Na}_{2} \mathrm{SO}_{4}, \mathrm{CaCl}_{2}$ and $\mathrm{MgSO}_{4}$ using Quadratic Equation.10 Kg soil was used to fill each pot. 10 seeds of Niazboo (Ocimum basilicum) as medicinal plant were sown in each pot. Fertilizer was applied @50-45-40 NPK Kg ha'-1. Treatments were $\left(4 \mathrm{dSm}^{-1}+13.5\left(\mathrm{mmol} \mathrm{L}^{-1}\right) 1 / 2,5 \mathrm{dSm}^{-1}+25\left(\mathrm{mmol} \mathrm{L}^{-1}\right) 1 / 2\right.$, $5 \mathrm{dSm}^{-1}+30\left(\mathrm{mmol} \mathrm{L}^{-1}\right)^{1 / 2}, 10 \mathrm{dSm}^{-1}+25\left(\mathrm{mmol} \mathrm{L}^{-1}\right)^{1 / 2}, 10 \mathrm{dSm}^{-1}$ $+25\left(\mathrm{mmol} \mathrm{L}^{-1}\right)^{1 / 2}$ and $\left.10 \mathrm{dSm}^{-1}+30\left(\mathrm{mmol} \mathrm{L}^{-1}\right)^{1 / 2}\right)$. Completely randomized deign was applied with three repeats. Data on biomass yield were collected. Collected data were statistically analysed and means were compared by LSD at $5 \%$ [39].

\section{Results and Discussion}

Intense salinity decreases efficiency of many crops including most vegetables by causing various irregular morphological, physiological and biochemical alternations that basis late germination, high seedling transience, poor plant population, diminutive growth and lower yields. Biosaline agriculture 
(utilization of these salt- affected lands without disturbing present condition) is an economical way to reclaim the saltaffected soils and bring this area under cultivation. Keeping in view, a pot study was carried out to assess the salt tolerance of Niazboo (Ocimum basilicum) under different salt concentrations. Significant divergence was initiated with treatments on biomass yield (Table-1). Highest biomass yield (43.10gpot $\left.{ }^{-1}\right)$ was gained by $4 \mathrm{dSm}^{-1}+13.5\left(\mathrm{mmol} \mathrm{L}^{-1}\right)^{1 / 2}$ treatment. Biomass yield was decreased as well as the toxicity of salts was increased. Minimum biomass yield (30.33 gpot $\left.^{-1}\right)$ was produced at $10 \mathrm{dSm}^{-1}+30(\mathrm{mmol}$ $\left.\mathrm{L}^{-1}\right)^{1 / 2}$. Germination and seedling emergence may be influenced by temperature, sowing depth and seedbed conditions like available moisture and salinity $[40,41]$. Salinity leads to delayed germination and emergence, low seedling survival, irregular crop stand and lower yield due to abnormal morphological, physiological and biochemical changes [42,43].

Table 1: Effect of various salinity and sodicity levels on biomass yield of Niazboo (Ocimum basilicum) as medicinal crop.

\begin{tabular}{|c|c|c|}
\hline Treatments & $\begin{array}{c}\text { Biomass yield } \\
\left(\text { gpot }^{-1}\right)\end{array}$ & $\begin{array}{l}\% \text { Decrease } \\
\text { over control }\end{array}$ \\
\hline $\begin{array}{c}\mathrm{ECe}=4 \mathrm{dSm}-1+\mathrm{SAR}=13.5(\mathrm{mmol} \\
\mathrm{L}-1) 1 / 2\end{array}$ & $43.10 \mathrm{a}$ & ------- \\
\hline $\begin{array}{c}\mathrm{ECe}=5 \mathrm{dSm}-1+\mathrm{SAR}=25(\mathrm{mmol} \\
\mathrm{L}-1) 1 / 2\end{array}$ & $38.00 \mathrm{a}$ & 11.83 \\
\hline $\begin{array}{c}\mathrm{ECe}=5 \mathrm{dSm}-1+\mathrm{SAR}=30(\mathrm{mmol} \\
\mathrm{L}-1) 1 / 2\end{array}$ & 36.33ab & 15.7 \\
\hline $\begin{array}{c}\mathrm{ECe}=10 \mathrm{dSm}-1+\mathrm{SAR}=25(\mathrm{mmol} \\
\mathrm{L}-1) 1 / 2\end{array}$ & $35.83 \mathrm{~b}$ & 16.86 \\
\hline $\begin{aligned} \mathrm{ECe}= & 10 \mathrm{dSm}-1+\mathrm{SAR}=30 \\
& (\mathrm{mmol} \mathrm{L}-1) 1 / 2\end{aligned}$ & $30.33 b c$ & 29.62 \\
\hline LSD at $5 \%$ & 5.23 & \\
\hline
\end{tabular}

Table 1 also explained the $\%$ decrease in biomass yield over control. $5 \mathrm{dSm}^{-1}+25\left(\mathrm{mmol} \mathrm{L}^{-1}\right)^{1 / 2}$ treatment performed better results i.e. the least reduction \% over control (11.83). Salinitysodicity showed serious effect on the growth reduction from 11.83 to $29.62 \%$. This huge fissure was impacted by the negative effect of salinity cum sodicity on Niazboo (Ocimum basilicum) growth. Salinity- sodicity showed staid effect on the growth reduction from 11.83 to $29.62 \%$. This reduction fissure was impacted by the harmful effect of salinity and sodicity on coriander growth. Salinity- sodicity behaved toxic impact on the growth reduction from 11.83 to $29.62 \%$. Such problems affect water and air movement, plant-available water holding capacity, root penetration, runoff, erosion and tillage and sowing operations. In addition, imbalances in plant-available nutrients in both saline and sodic soils affect plant growth [44-48].

\section{Conclusion}

Based on the findings, Niazboo (Ocimum basilicum) was able to how grow against more salt tolerance at $4 \mathrm{dSm}^{-1}+13.5$ (mmol L $\left.{ }^{-1}\right)^{1 / 2}$ treatment. Therefore, Niazboo (Ocimum basilicum) is suggested to be cultivated in farmlands having salinity cum sodicity up to. $4 \mathrm{dSm}^{-1}+13.5\left(\mathrm{mmol} \mathrm{L}^{-1}\right)^{1 / 2}$.

\section{References}

1. Khan MA, Duke NC (2001) Halophytes- A resource for the future. Wetland Ecology and Management 6: 455-456.

2. Munns R (2005) Genes and salt tolerance: bringing them together. New Phytol. 167(3): 645-663.

3. Essa TA (2002) Effect of salinity stress on growth and nutrient composition of three soybean (Glycine $\max ($ L.) Merrill) cultivars. Journal of Agronomy \& Crop Science188(2): 86-93.

4. FAO (2000) Global network on integrated soil management for sustainable use of salt-affected soils.

5. Maghsoudi AM, Maghsoudi K (2008) Salt stress effect on respiration and growth of germinated seeds of different Wheat (Triticum sativum L.) cultivars. World Journal of Agricultural Sciences 4 (3): 351-358.

6. Cha-um S, Pokasombat Y, Kirdmanee C (2011) Remediation of salt affected soil by gypsum and farmyard manure-Importance for the production of Jasmine rice. Aust J Crop Sci 5(4): 458-465.

7. Nasser JY Sholi (2012) Effect of Salt Stress on Seed Germination, Plant Growth, Photosynthesis and Ion Accumulation of four Tomato Cultivars. American Journal of Plant Physiology 7(6): 269-275.

8. Moradi P, Zavareh M (2013) Effects of salinity on germination and early seedling growth of chickpea (Cicer arietinum $L$.) cultivars Intl J Farm Alli Sci 2 (3): 70-74

9. Zeinolabedin J (2012) The Effects of Salt stress on plant growth. Technical Journal of Engineering and Applied Sciences (TJEAS) 2 (1): 7-10.

10. Omidbaig R (2005) Production and Processing of Medicinal Plants. Astane Quds Publ Tehran 438.

11. Wang WB, YH Kim, HS Lee, KY Kim, SS Kwask (2009) Analysis of antioxidant enzymes activity during germination of alfalfa under salt and drought stresses. Plant Physiol Biochem 47(7): 570-577.

12. Miceli A, Moncada A, D Anna F (2003) Effect of water salinity on seedsgermination of Ocimum basilicum L, Erucasativa $L$ and Petroselinum hortense, Hoffm. Acta Horticulturae 609: 365-370.

13. Ramin AA (2005) Effects of salinity and temperature on germination and seedling establishment of sweet basil (Ocimum basilicum L). Journal of Herbs, Spices and Medicinal Plant 11: 81-90.

14. Ali RM, Abbas HM, Kamal RK (2007) The effects of treatment with polyaminesondry matter, oil and flavonoid contents in salinity stressed chamomile and sweet marjoram. Plant, Soil and Environment 53(12): 529-543.

15. Belaqziz R, Romane A, Abbad A (2009) Salt stress effects ongermination, growth and essential oil content of an endemic thyme speciesin Morocco (Thymus maroccanus Ball). Journal of Applied Sciences Research 5(7): 858-863.

16. Shalan MN, Abdel-Latif TAT, Ghadban EA (2006) Effect of watersalinity and some nutritional compounds on the growth and production of sweet marjoram plants (Majorana hortensis L). Egyptian Journal of Agricultural Research 84: 959.

17. Aziz EE, Al-Amier H, Craker LE (2008) Influence of salt stress on growth and essential oil production in peppermint, pennyroyal, and apple mint. Journal of Herbs, Spices and Medicinal Plants 14: 77-87.

18. Leithy S, Gaballah Ms, Gomaa AM (2009) Associative impact of bio-and organic fertilizers on geranium plants grown under saline conditions. International Journal of Academic Research 3(3): 17-23.

19. Najafian S, Khoshkhui M, Tavallali V, Saharkhiz MJ (2009) Effect of salicylic acid and salinity in thyme (Thymus vulgaris L.): investigation on changes in gasex change, water relations, and membrane stabilization and biomass accumulation. Australian Journal of Basic and Applied Sciences 3: 2620-2626. 
20. Ben Taarit MK, Msaada K, Hosni KM, Hammami M, Kchouk E, et al. (2009) Plant growth, essential oil yield and composition of sage (Salvia officinalis L.) fruits cultivated under salt stress conditions. Industrial Crops and Products 30(3): 333-337.

21. Queslati S, Karray-Bouraoui N, Attia H, Rabhi M, Ksouri R, et al. (2010) Physiological and antioxidant responses of Mentha pulegium (Pennyroyal) to salt stress. Acta Physiologiae Plantarum 32(2): 289296.

22. Telci I, Bayram E, Yilmaz G, Avci B (2006) Variability in essential oil composition of Turkish basils (Ocimum basilicum L.). Biochemical Systematic and Ecology 34: 489-497.

23. Kéita SM, Vincent C, Schmit J, Arnason JT, Bélanger A (2001) Efficacy of essential oil of Ocimum basilicum L. and O. gratissimum L. applied as an insecticidal fumigant and powder to control Callosobruchus maculatus (Fab). J Stored Prod Res 37(4): 339- 349.

24. Negrelle RR, Gomes EC (2007) Cymbopogon citratus (DC) Stapf: Chemical Composition and Biological Activities. Revista Brasileira De Plantas Medicinais, Botucatu 9(1): 80-92.

25. Celik TA, Aslantürk OS (2006) Anti-mitotic and anti-genotoxic effects of Plantago lanceolata aqueous extracts on Allium cepa root tip meristem cells. Biologia 61(6): 693-697.

26. Celik TA, Aslantürk OS (2007) Cytotoxic and genotoxic effects of Lavandula stoechas aqueous extracts. Biologia 62(3): 292-296.

27. Pugliesi GC, Andrade SF, Bastos JK, Maistro EL (2007) In vivo clastogenicity assessment of the Austroplenckia populnea (Celastraceae) leaves extract using micronucleus and chromosomes aberration assay. Cytologia 72(1): 1-6.

28. Lubini G, Fachinetto JM, Laughinghouse HD, Paranhos JT, Silva ACF, et al. (2008) Extracts affecting mitotic division in root-tip meristematic cells. Biologia 63(5): 647-651.

29. Nunes WB, Carvalho S (2003) Avalia o dos efeitos clastogênicos do algod.ozinho-do-campo-Cochlospermun regium (Mart ex Schrank) pilger, em células germinativas de Drosophila melanogaster. Genet Mol Biol 26: 545-549.

30. Ballhorn DJ, Kautz S, Heil M, Hegeman AD (2009) Analyzing plant defenses in nature. Plant Signal Behav 4(8): 743-745.

31. Verpoorte R, Memelink J (2002) Engineering secondary metabolite production in plants. Current Opinion in Biotechnology 13(2): 181187.

32. Bourgaud F, Gravot A, Milesi S, Gontier E (2001) Production of plant secondary metabolites: A historical perspective. Plant Science 161(5): 839-851.

33. Edris AE (2007) Pharmaceutical and therapeutic potentials of essential oils and their individual volatile constituents: a review. Phytother Res 21(4): 308-323.

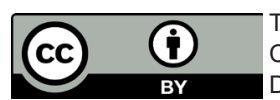

is work is licensed under Creative

Commons Attribution 4.0 Licens

DOI: 10.19080/AIBM.2019.12.555846
34. Bakkali F, Averbeck S, Averbeck D, Idaomar M (2008) Biological effects of essential oils a review. Food and Chemical Toxicology 46(2): 446475 .

35. Yuan G, Wahlqvist ML, He G, Yang M, Li D (2006) Natural products and anti-inflammatory activity. Asian Pac J Clin Nutr 15(2): 143-152.

36. Boukhatem MN, Kameli A, Ferhat MA, Saidi F, Tayebi K (2014) The food preservative potential of essential oils: is lemongrass the answer. Journal für Verbraucherschutz und Lebensmittelsicherheit 9(1): 1321.

37. Taher YA (2012) Antinociceptive activity of Mentha piperita leaf aqueous extract in mice. Libyan J Med 7: 16205.

38. Dub AM, Dugani AM (2013) Antithrombotic effect of repeated doses of the ethanolic extract of local olive (Olea europaea $L$ ) leaves in rabbits. Libyan J Med 8(1): 20947.

39. Montgomery DC (2001) Design and Analysis of Experiments ( $5^{\text {th }}$ Edn.) John Willey and Sons, New York, USA, p. 64-65.

40. Couture SJ, A Di Tommaso, WL Asbil, AK Watson (2004) Influence of seeding depth and seedbed preparation on establishment, growth and yield of fibre flax (Linum usitatissimum $L$ ) in Eastern Canada. Journal of Agronomy and Crop Science 190(3): 184-190.

41. Kurt O, D Bozkurt (2006) Effect of temperature and photoperiod on seedling emergence of flax (Linum usitatissimum L.). Journal of Agronomy 5(3): 541-545.

42. Munns R (2002) Comparative physiology of salt and water stress. Plant Cell and Environment 25(2): 239-250.

43. Muhammad Z, Hussain F (2010) Effect of $\mathrm{NaCl}$ salinity on the germination and seedling growth of some medicinal plants. Pakistan Journal of Botany 42(2): 889-897.

44. Qadir M, Schubert S (2002) Degradation processes and nutrient constraints in sodic soils. Land Degradation \& Development 13(4): 275-294.

45. FAO (2008) Land and Plant Nutrition Management Service.

46. Selmar D, Kleinwachter M (2013) Influencing the product quality by deliberately applying drought stress during the cultivation of medicinal plants. Industrial Crops and Products 42: 558-566.

47. Shackleton CM, Timmermans HG, Nongwe N, Hamer N, Palmer NR (2007) Direct-use values of non-timber forest products from two areas on the Transkei Wild Coast. Agrekon 46: 113-134.

48. Shah G, Shri R, Panchai V, Sharma N, Singh B, et al. (2011) Scientific basis for the therapeutic use of Cymbopogon citratus stapf (lemon grass). J Adv Pharm Technol Res 2(1): 3-8.

\section{Your next submission with Juniper Publishers will reach you the below assets}

- Quality Editorial service

- Swift Peer Review

- Reprints availability

- E-prints Service

- Manuscript Podcast for convenient understanding

- Global attainment for your research

- Manuscript accessibility in different formats

( Pdf, E-pub, Full Text, Audio)

- Unceasing customer service

Track the below URL for one-step submission

https://juniperpublishers.com/online-submission.php 